\title{
Yield Maximization of Rice (Oryza sativa, L.) through Site Specific Nutrient Management under Medium Deep Black Clay Soils of Tungabhadra Command
}

\author{
B. G. Masthana Reddy*, K. Mahantashivayogayya, Sujay Hurali and S.B. Gowdar
}

All India Co-ordinated Rice Improvement Programme, Agricultural Research Station, Gangavathi-583 227

University of Agricultural Sciences, Raichur, Karnataka (INDIA)

*Corresponding author

\section{A B S T R A C T}

\section{Keywords}

Site specific nutrient management, Nutrient expert, Transplanted rice, LCC

\section{Article Info}

Accepted: 18 May 2020 Available Online: 10 June 2020
Field experiment was conducted at Agricultural Research Station, Gangavathi, Karnataka during the rainy season of 2014, 2015 and 2016 to evaluate "Nutrient expert" a decision supporting tool against farmers and recommended fertilizer practice to optimize fertilizer recommendations for transplanted rice. The treatments consisted of various fertilizer practices including recommended fertilizer practice compared with site specific nutrient management and leaf colour chart based $\mathrm{N}$ management. The results revealed that farmers practice with high fertilizer dose of 330:158:100 kg N, $\mathrm{P}_{2} \mathrm{O}_{5} \& \mathrm{~K}_{2} \mathrm{O} /$ ha recorded significantly higher mean grain yield of $69.91 \mathrm{q} / \mathrm{ha}$ as compared to Nutrient expert based application of $125: 37: 57 \mathrm{~kg} \mathrm{~N}, \mathrm{P}_{2} \mathrm{O}_{5} \& \mathrm{~K}_{2} \mathrm{O} /$ ha with a mean grain yield of $58.73 \mathrm{q} / \mathrm{ha}$. However Nutrient expert based NPK compares well with recommended fertilizer practice (62.0q/ha) and remained on par with it in all the years as well as in the mean yields. Nutrient expert based NPK resulted in 37, 63 and $43 \%$ saving in $\mathrm{N}, \mathrm{P}$ and $\mathrm{K}$ against recommended practice. The

\section{Introduction}

Rice is an important food crop of India, grown over an area of 43.44 mha with a production of $112.4 \mathrm{mt}$ and with a productivity of 2.5t/ha (Anon 2016). At the current population growth rate of $1.5 \%$ the rice requirement projected by Indian Institute of Rice Research would be around $156 \mathrm{mt}$ by 2030. Fertilizers and irrigation are two key factors in increasing the rice productivity. The current blanket fertilizer applications followed by the farmers in Tungabhadra command in Karnataka are high and imbalanced resulting in huge losses of nutrients with reduced nutrient efficiency and 
environmental pollution. A survey on fertilizer practice followed by the farmers in the command revealed that the average fertilizer consumption is about 330:158:100 $\mathrm{kg} \mathrm{N}, \mathrm{P}_{2} \mathrm{O}_{5}$ and $\mathrm{K}_{2} \mathrm{O} /$ ha and their soil analysis revealed that high levels of soil residual Phosphorus of $125 \mathrm{~kg} \mathrm{P}_{2} \mathrm{O}_{5} / \mathrm{ha}$ and potassium levels of $460 \mathrm{~kg} \mathrm{~K}_{2} \mathrm{O} / \mathrm{ha}$. Hence there is need for optimizing fertilizers applications for sustainable production rice without deteriorating soil and environment. The International plant nutrition Institute(IPNI), Hyderabad in collaboration with ICAR has developed " Nutrient expert for rice" a easy to use, interactive and computer based decision support tool that provide field specific nutrient recommendations in presence or absence of soil testing data. The tool is software programme with inbuilt questionnaire and farmers need to fill the information regarding site specific rice cultivation practices including fertilizer practices adopted by the farmer and the yield levels harvested by the farmers. The software finally provides the actual amounts of market available fertilizers to be applied. In the present investigation the "nutrient expert for rice" was evaluated against farmers and recommended fertilizer practices in transplanted rice.

\section{Materials and Methods}

Field experiment was conducted during the rainy season of 2014, 2015 and 2016 at the Agricultural Research Station, Gangavati, Karnataka. The soil of the experimental site was medium deep black clay in texture, neutral to alkaline in reaction ( $\mathrm{pH} 8.2$ to 8.4 ) and low in electrical conductivity ( 0.40 to $0.65 \mathrm{dS} / \mathrm{m})$. The soil was low in available $\mathrm{N}$ $\left(230 \mathrm{~kg} \mathrm{ha}^{-1}\right)$, high in available $\mathrm{P}_{2} \mathrm{O}_{5}(80.5 \mathrm{~kg}$ $\left.\mathrm{ha}^{-1}\right)$ and high in exchangeable $\mathrm{K}_{2} \mathrm{O}(390 \mathrm{~kg}$ $\mathrm{ha}^{-1}$ ) in the surface $0-20 \mathrm{~cm}$ depth. Eight treatments consisting of $\mathrm{T}_{1}$ : Recommended fertilizer practice (200:100:100 $\mathrm{kg} \quad \mathrm{N}, \mathrm{P}_{2} \mathrm{O}_{5}$ $\left.\& \mathrm{~K}_{2} \mathrm{O} / \mathrm{ha}\right), \mathrm{T}_{2}$ : SSNM(site specific nutrient management) based on nutrient expert $\left(125: 37: 57 \mathrm{~kg} \quad \mathrm{~N}, \quad \mathrm{P}_{2} \mathrm{O}_{5}\right.$ and $\left.\mathrm{K}_{2} \mathrm{O} / \mathrm{ha}\right)$, $\mathrm{T}_{3}: \mathrm{SSNM}$ based on leaf colour chart(LCC) $(50 \% \mathrm{~N}$ as basal and the rest based on LCC), $\mathrm{T}_{4}: \mathrm{T}_{2}$ minus $\mathrm{N}, \mathrm{T}_{5}: \mathrm{T}_{2}$ minus $\mathrm{P}, \mathrm{T}_{6}$ : $\mathrm{T}_{2}$ minus $\mathrm{K}, \mathrm{T}_{7}$ : Absolute control (No N:P:K) and $\mathrm{T}_{8}$ :farmers fertilizer practice (330:158:100 kg N, $\mathrm{P}_{2} \mathrm{O}_{5} \& \mathrm{~K}_{2} \mathrm{O} / \mathrm{ha}$ ) were tried in RBD design with three replications. GGV05-01 variety of medium duration rice was used. Thirty days aged seedlings were transplanted at a spacing of $20 \times 10 \mathrm{~cm}$ spacing on $19^{\text {th }}$ August, $16^{\text {th }}$ August and $14^{\text {th }}$ August during 2014, 2015 and 2016 respectively. In the case of leaf colour chart (LCC) a critical value of 5 was used to schedule $\mathrm{N}$. The recommended plant protection measures were followed. Observations on yield and yield parameters were recorded, soil analysis for $\mathrm{N}$, $\mathrm{P}$ and $\mathrm{K}$ was carried out, statistically analysed and presented.

\section{Results and Discussion}

\section{Effect on grain yield}

The grain yield of rice (Table 1) was significantly higher in the case of farmers fertilizer practice (330:158:100 $\mathrm{kg} \mathrm{N}, \mathrm{P}_{2} \mathrm{O}_{5}$ \& $\mathrm{K}_{2} \mathrm{O} / \mathrm{ha}$ ) as compared to other treatments recording 51.99, 63.50 and $94.24 \mathrm{q} / \mathrm{ha}$ respectively during 2014, 2015 and 2016 and with a mean yield of $69.91 \mathrm{q} / \mathrm{ha}$. The next best treatment appeared was recommended practice with a fertilizer dose of 200:100:100 $\mathrm{kg} \mathrm{N}, \mathrm{P}_{2} \mathrm{O}_{5} \& \mathrm{~K}_{2} \mathrm{O} /$ ha which recorded a mean grain yield of $62.00 \mathrm{q} / \mathrm{ha}$. This is closely followed by LCC based NPK application (59.07q/ha) and nutrient expert based NPK application with a mean grain yield of 58.73 $\mathrm{q} /$ ha. The nutrient expert remained on par in grain yield with recommended practice in two out of three years as well as in the mean data. Contrarily to the present results Abhishek Shrestha et al., (2016) and Ganesh Gupta et 
al., (2016) reported that nutrient expert based NPK application recorded higher grain yield than farmers and government recommended practice. However, Mirasol et al., (2012) reported that nutrient expert for maize increased the yield and profit of maize by increasing the fertilizer application rates in Philippines.

\section{Yield parameters}

The number of panicles per square meter (sqm) were significantly higher in the case of farmers practice (372 no/sqm) than other treatments but remained on par with recommended fertilizer practice (367 no). Whereas, the panicles in nutrient expert (347 no) remained on par with recommended practice.

The panicle weight was significantly higher in the case of farmers fertilizer practice $(3.04 \mathrm{~g})$ followed by recommended practice $(2.69 \mathrm{~g})$ and nutrient expert (2.66 g). These parameters have contributed for higher grain yield in the above treatments.

\section{Indigenous nutrient supply}

The indigenous nutrient supplying capacity measured in terms of grain yield revealed that applying $\mathrm{P}$ and $\mathrm{K}$ alone without $\mathrm{N}$ resulted in lower grain yields of $41.8 \mathrm{q} / \mathrm{ha}$ indicating the importance of $\mathrm{N}$ in the grain yield formation. As compared with recommended practice there was a yield reduction of 32.5, 7.7 and $6.2 \%$ respectively without $\mathrm{N}, \mathrm{P}$ and $\mathrm{K}$.

This indicated that yields were adversely affected in the absence of $\mathrm{N}$ application while without $\mathrm{P}$ and $\mathrm{K}$ there was a less reduction in yield. This might be attributed to high initial soil $\mathrm{P}$ and $\mathrm{K}$ status which supported the yield even without external application of $\mathrm{P}$ and $\mathrm{K}$.

\section{Savings in NPK due to Nutrient expert}

One of the advantages of the nutrient expert is that its grain yield remained on par with recommended fertilizer practice while there was a considerable saving in $\mathrm{N}, \mathrm{P}$ and $\mathrm{K}$ to an extent of $37 \% \mathrm{~N}, 63 \% \mathrm{P}_{2} \mathrm{O}_{5}$ and $43 \% \mathrm{~K}_{2} \mathrm{O}$ as compared to recommended practice. In contrast, though there was a huge saving to an extent of $62 \% \mathrm{~N}, 76 \% \mathrm{P}_{2} \mathrm{O}_{5}$ and $43 \% \mathrm{~K}_{2} \mathrm{O}$ in the case of nutrient expert as compared to farmers practice yet grain yield were higher in farmers practice mainly due to very high amount of fertilizer applications.

\section{Soil available $\mathbf{N}, \mathbf{P}$ and $\mathrm{K}$}

The soil analysis data (Table 2) revealed that available $\mathrm{N}$ was significantly higher in the case of $\mathrm{T}_{3}$ minus $\mathrm{N}$ due to lower grain yield in the treatment leading to high soil $\mathrm{N}$. The available soil $\mathrm{P}$ was significantly higher in the case of absolute control probably due to lower grain yield and high initial $\mathrm{P}$ status. There was no significant difference in exchangeable soil $\mathrm{K}$ among different treatments due to high initial soil $\mathrm{K}$ values.

\section{Economics}

The economics (Table 3) revealed that the net returns were significantly higher in the case of farmers fertilizer practice in all the three years with a mean net returns of Rs $84779 /$ ha. This was mainly due to higher grain yields as a result of application of very high amounts of fertilizers. However, in spite of higher grain yields in the case of farmers practice, the net returns in the case of Nutrient expert remained on par with farmers practice in two out of three years. Similarly, in all the years the net returns in nutrient expert remained on par with recommended practice indicating economic profitability of nutrient expert. 
Table.1 Grain yield and yield parameters of transplanted rice as influenced by nutrient expert

\begin{tabular}{|c|c|c|c|c|c|c|c|}
\hline \multirow[t]{2}{*}{ reatments } & \multicolumn{4}{|c|}{ Grain yield(q/ha) } & \multirow{2}{*}{$\begin{array}{l}\text { o. of Panicles } \\
\text { /sqm } \\
(2014-16)\end{array}$} & \multirow{2}{*}{$\begin{array}{c}\begin{array}{c}\text { Panicle } \\
\text { weight }(g)\end{array} \\
(2014-16)\end{array}$} & \multirow{2}{*}{\begin{tabular}{|c|} 
Test \\
weight $(\mathrm{g})$ \\
$(2014-16)$ \\
\end{tabular}} \\
\hline & 2014 & 2015 & 2016 & Mean & & & \\
\hline $\mathbf{T 1}$ & 44.54 & 60.42 & 81.02 & 62.00 & 367 & 2.69 & 16.25 \\
\hline $\mathbf{T 2}$ & 45.80 & 57.02 & 73.37 & 57.73 & 347 & 2.66 & 16.37 \\
\hline T3 & 44.57 & 57.00 & 75.65 & 59.07 & 338 & 2.48 & 15.99 \\
\hline $\mathbf{T 4}$ & 39.02 & 39.25 & 47.13 & 41.80 & 304 & 2.21 & 15.24 \\
\hline T5 & 47.22 & 55.67 & 68.72 & 57.20 & 327 & 2.60 & 17.24 \\
\hline T6 & 44.69 & 55.75 & 73.97 & 58.14 & 347 & 2.43 & 15.84 \\
\hline T7 & 41.08 & 37.50 & 39.18 & 39.25 & 295 & 2.05 & 15.71 \\
\hline T8 & 51.99 & 63.50 & 94.24 & 69.91 & 372 & 3.04 & 16.81 \\
\hline SEm & 0.75 & 2.13 & 2.11 & 1.18 & 7.52 & 0.06 & 0.28 \\
\hline $\mathrm{D}(\mathrm{p}=\mathbf{0 . 0 5})$ & 2.20 & 6.27 & 6.21 & 3.49 & 22.10 & 0.20 & 0.84 \\
\hline
\end{tabular}

Table.2 Available soil N, P and K as influenced by Nutrient expert in transplanted rice

\begin{tabular}{|c|c|c|c|}
\hline Treatments & Av.N(kg/ha) & Av.P(kg/ha) & Av.K(kg/ha) \\
\hline T1 & 167.27 & 41.46 & 337.06 \\
\hline T2 & 190.23 & 36.51 & 316.98 \\
\hline T3 & 127.53 & 32.25 & 308.84 \\
\hline T4 & 198.60 & 35.35 & 327.52 \\
\hline T5 & 173.53 & 38.28 & 311.28 \\
\hline T6 & 179.80 & 32.09 & 309.45 \\
\hline T7 & 181.87 & 43.43 & 338.39 \\
\hline T8 & 175.63 & 38.72 & 318.08 \\
\hline SEm & 9.56 & 1.82 & 10.74 \\
\hline CD(p=0.05) & 28.14 & 5.35 & NS \\
\hline
\end{tabular}

Table.3 Economics of transplanted rice as influenced by Nutrient expert

\begin{tabular}{|c|c|c|c|c|c|c|c|c|}
\hline Treatments & \multicolumn{4}{|c|}{ Net returns (Rs/ha) } & \multicolumn{4}{c|}{ Benefit-cost ratio } \\
\hline & $\mathbf{2 0 1 4}$ & $\mathbf{2 0 1 5}$ & $\mathbf{2 0 1 6}$ & $\mathbf{M e a n}$ & $\mathbf{2 0 1 4}$ & $\mathbf{2 0 1 5}$ & $\mathbf{2 0 1 6}$ & Mean \\
\hline $\mathbf{T 1}$ & 32681 & 62109 & 127219 & 74003 & 1.66 & 2.25 & 3.56 & 2.49 \\
\hline $\mathbf{T 2}$ & 39685 & 60973 & 115504 & 72054 & 1.89 & 2.36 & 3.58 & 2.61 \\
\hline T3 & 36846 & 60401 & 120381 & 72542 & 1.82 & 2.34 & 3.67 & 2.61 \\
\hline T4 & 28912 & 29688 & 60598 & 39733 & 1.67 & 1.69 & 2.41 & 1.92 \\
\hline T5 & 44048 & 60128 & 108024 & 70733 & 2.02 & 2.40 & 3.51 & 2.64 \\
\hline T6 & 39000 & 59970 & 119282 & 72751 & 1.90 & 2.38 & 3.75 & 2.68 \\
\hline T7 & 36693 & 30331 & 46867 & 37964 & 1.94 & 1.78 & 2.20 & 1.97 \\
\hline T8 & 40636 & 62549 & 151151 & 84779 & 1.74 & 2.14 & 3.74 & 2.54 \\
\hline SEm & 1338 & 3954 & 4578 & 2391 & 0.03 & 0.09 & 0.10 & 0.05 \\
\hline $\mathbf{C D}(\mathbf{p = 0 . 0 5})$ & 3935 & 11632 & 13466 & 7034 & 0.09 & 0.27 & 0.30 & 0.16 \\
\hline
\end{tabular}


The findings are in line with Veer singh et al., (2017) wherein Nutrient expert based NPK application for maize hybrids resulted in higher profits over $100 \%$ RDF in maize-wheat cropping system. The benefit-cost ratio (BCR) revealed that treatments with no $\mathrm{P}$ and $\mathrm{K}\left(\mathrm{T}_{5} \& \mathrm{~T}_{6}\right)$ recorded significantly higher $\mathrm{BCR}$ than other treatments. Further BCR in the case of nutrient expert remained on par with recommended fertilizer practice in all the years.

The three year data clearly indicated that farmers practice fared well in terms of grain yield and net returns as compared to nutrient expert. However when compared with recommended practice the net returns and $\mathrm{BC}$ ratio in the case of Nutrient expert remained on par with recommended practice besides resulting in savings in $\mathrm{N}, \mathrm{P}$ and $\mathrm{K}$ and therefore can be recommended for adoption by the farmers.

\section{References}

Anonymous, Agricultural statistics at a glance 2016. GOI, Ministry of Agriculture and farmers welfare, Dept of Agriculture, Co-operation \& farmers welfare, Directorate of Economics \& Statistics.
Abhishek shrestha, Ganesh Gupta, Abhimanyu shreshtha and Roshan subedi. 2016. Evaluation of improved nutrient management practices in yield of rice in Jhapa district. International Journal of Research in applied, natural and social Sciences 4(3):67-74.

Ganesh Gupta, Abhishek shreshtha, Abhimanyu shreshtha and Lal Prasad Amgain. 2016. Evaluation of different nutrient management practices in yield and growth in rice in Morang district. Advances in Plants and Agriculture Research, 3(6):1-5.

Mirasol F, Pampolino, Christian witt, Julie Mae Pasuquin, Adrian Johnston and Myles Fisher. 2012. Development approach and evaluation on nutrient expert software for nutrient management in cereal crops. Computers and Electronics in Agriculture 88:103110.

Veer Singh, Anilkumar Pant, Amit Bhatnagar and Manish Bhatt. 2017. Evaluation of nutrient expert based fertilizer recommendations for growth, yield and nutrient uptake of Maize hybrids and soil properties in Maize-wheat cropping system in Mollisol. International Journal of Current Microbiology and Applied Sciences 6(10): 3539-3550.

\section{How to cite this article:}

Masthana Reddy, B. G., K. Mahantashivayogayya, Sujay Hurali and Gowdar, S.B. 2020. Yield Maximization of Rice (Oryza sativa L.) through Site Specific Nutrient Management under Medium Deep Black Clay Soils of Tungabhadra Command. Int.J.Curr.Microbiol.App.Sci. 9(06): 1646-1650. doi: https://doi.org/10.20546/ijcmas.2020.906.203 